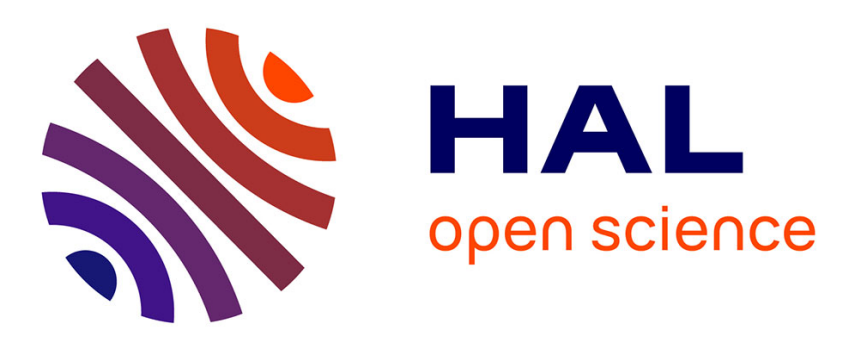

\title{
Social provisioning and financial regulation: An Institutionalist-Minskyian agenda for reform Faruk Ulgen
}

\section{To cite this version:}

Faruk Ulgen. Social provisioning and financial regulation: An Institutionalist-Minskyian agenda for reform. ASE at ASSA annual meetings "Commodities, commodification and alternatives to exchange", Association for social economics, Allied social science association, Jan 2015, Boston, United States. halshs-01111183

\section{HAL Id: halshs-01111183 \\ https://shs.hal.science/halshs-01111183}

Submitted on 29 Jan 2015

HAL is a multi-disciplinary open access archive for the deposit and dissemination of scientific research documents, whether they are published or not. The documents may come from teaching and research institutions in France or abroad, or from public or private research centers.
L'archive ouverte pluridisciplinaire HAL, est destinée au dépôt et à la diffusion de documents scientifiques de niveau recherche, publiés ou non, émanant des établissements d'enseignement et de recherche français ou étrangers, des laboratoires publics ou privés. 


\section{Social provisioning and financial regulation: An Institutionalist-Minskyian agenda for reform}

\section{Abstract (147 words)}

This article seeks to put social provisioning into perspective with regard to the financial instability issue in capitalism. The analysis rests on an institutionalist-Minskyian endogenous instability assumption and maintains that monetary/financial stability is a peculiar public good or specific commons since it concerns the whole society and its viability conditions in time and not only the individuals involved in private financial relations. Consequently, the provision of financial stability becomes essentially a matter of public policy and requires the intervention of public power in order to prevent finance from becoming a public bad. This result relies on the distinction between private "normal" goods and ambivalent/transversal money (and related financial relations). It then points to the necessity of a public organization and tight regulation of finance and financial markets while standard equilibrium models assume that social optimum and stability can be provided by private self-adjustment and market prices mechanisms.

\section{Author}

\section{Faruk ÜLGEN}

Centre de Recherche en Economie de Grenoble (CREG)

Head of the Branch campus of Valence, Grenoble Faculty of Economics

University of Grenoble Alpes, France

Keywords: commons, financial instability, institutions, public goods, regulation, social provisioning

JEL Classification Codes: B52, D71, G01, G18, H41 
Word Count: 2829 words (text only)

This article aims at studying social provisioning in relation with the problem of financial instability and argues that monetary/financial stability is a peculiar "collective/public good" that every member of society needs but no one can provide at individual level.

Studies on public goods, commons, collective action and group coordination are usually conducted in terms of arbitraging process, agency relations and economic efficiency ${ }^{1}$. However, the present research maintains that such utilitarian-like analyses are not apt to deal with the very characteristics of monetary/financial relations and related instabilities ${ }^{2}$. In an alternative institutionalist-Minskyian stance, it assumes that financial instability is the normal functioning of a capitalist economy since production/investment activities depend upon private expectations about the future (but uncertain) profits and need external financing that continuously generates business debts. So the continuity of the accumulation process relies on the systemic validation of the debt structure. As there is no guarantee to socially validate private debts, some collective rules/mechanisms are required to guide private actors with respect to the "red lines" of systemic stability. Providing these red lines and supervising market behavior regarding them is the provision of financial stability which is a part of social provisioning.

This article develops those assertions through three sections. The first section specifies the links between social provisioning, public goods and financial stability and argues that financial stability cannot be entrusted to market mechanisms as in the case of "normal" privatizable goods. The second section states the specific/societal character of money and financial relations to provide analytical support to this assertion. The third section draws implications in favor of public framework and tight regulation to make the organization and supervision of monetary/financial markets more consistent with systemic stability. 


\section{Social provisioning and financial stability as a public good}

The functioning and evolution of capitalism as well as its social structure and institutional patterns are the domains of analysis par excellence of the institutional economics. Dugger (1996: 36) contrasts neoclassical economics with institutionalism by arguing that economics must be redefined as the study of social provisioning and a processual paradigm. Likewise, Gruchy (1987) and contributions in Lee (2012) and Lee and Lavoie (2013) see social provisioning as a major issue in institutionalism. Todorova (2013:62) defines it as the provision "for the material means of life which results in economic activities that generate the flow of goods and services that is necessary to meet the biological and socially-created needs of individuals and to maintain various social values." Power (2004) uses the concept to suggest alternative methodology in the feminist economics, and Tae-Hee (2011) shows how much social provisioning traverses different heterodox and institutionalist models. Institutionalists consider social provisioning from the perspective of social progress brought to the fore in the following quotation of Franklin D. Roosevelt ${ }^{3}$ : "The test of our progress is not whether we add more to the abundance of those who have much, it is whether we provide enough for those who have little".

The study of social provisioning then plays a central role as an alternative relevant way of analyzing the process of production-distribution-reproduction of goods and services in capitalist societies. Contrary to the mainstream economics' "Oratorical Glory of the Free Market"(Breger 2007: 57), institutionalists deny the market's role as a driving force in capitalism and claim that this view is inconsistent with the very characteristics of capitalist economies (Dugger 1988). Even if the market plays, at first sight, a central role, it is not a magic natural fact but a conscious construction based on some specific institutional and material structures. In a capitalist economy, even though it is assumed to be the central and sufficient social coordination mechanism for efficient production, the liberal market structure reveals to be 
unable to allow private-decentralized actors to take decisions that are globally compatible with each other. This way of approaching the problem also lies somewhat in the tradition of Polanyi as it means opposition between embedded and disembedded economies ${ }^{4}$.

The identification of social provisioning as the process of provision of goods/services that market mechanisms cannot ensure is related to the definition and characteristics of public goods and commons. Contrary to "rival and excludable" private goods which are produced and managed by profit-seeking private property, a public good is usually defined as non-excludable 5 and non-rival ${ }^{6}$. The production of such goods is supposed to belong to the public sphere and the market mechanisms are assumed to be no efficient to supply such activities. Public goods are then produced and managed under collective/public control in the aim of serving the whole community without profit objective. Parallel to this, one can also identify the commons which are rival but non-excludable; and common-pool resources with open/free access. Those goods pose the problem of efficient production and governing rules and oppose alternative systems such as coercive state, market pricing and voluntary organizations ${ }^{7}$. This constitutes a major chapter in institutional analysis of capitalism, initiated, among others, by the seminal works of Olson (1965), Hardin (1968) and Ostrom (1990). Olson (1965: 2) states that "If the members of a large group rationally seek to maximize their personal welfare, they will not act to advance their common or group objectives unless there is coercion to force them to do so, or unless some separate incentive, distinct from the achievement of the common or group interest, is offered to the members of the group individually on the condition that they help bear the costs or burdens involved in the achievement of the group objectives. (...) These points hold true even when there is unanimous agreement in a group about the common good and the methods of achieving it." And, Hardin (1968: 1247) maintains that "social arrangements that produce responsibility are arrangements that create coercion (...).” 
Apart from public and common goods and resources, economists also define club goods which are discriminatory and then excludable because, for instance, of some subscription fees to access goods. It is then assumed that private-markets can provide quantities to satisfy the demand. It is worth noting that in this vision it is implicitly supposed that there are no externalities of the use of club goods for non-members.

Following those criteria, the production of financial stability would depend on more public intervention or more liberal self-regulation mechanisms, according to its characteristics. So, one could wisely notice that financial instability generates serious externalities that can hurt all people badly as it can provoke severe underprovision/malprovision of public/common goods reducing thereby the wellbeing of low income population. Furthermore, in times of crisis, every citizen shoulders various negative consequences (unemployment, fall of investments, credit rationing, huge taxes, etc.) even if she/he is innocent bystander. Several emerging markets crises in the 1990s and early 2000s, but also the ongoing and long-lasting worldwide crisis, provide support to this assertion. Also at the international level, financial stability suffers from the free rider problem because each economy needs financial stability but self-interests and absence of tough international cooperation make free-rider behavior dominant. Each country tries to protect itself against the so-called international competition by not imposing restrictive regulation and supervision in the name of liberal market efficiency. This undermines the provision of financial stability as a global public good. Griffith-Jones (2013: 436) then asks "If excess volatility is the global public bad, what is the corresponding global public good?"

\section{Money and financial system as a part of social provisioning process}

The publicness of financial stability closely rests on the characteristics of money in a capitalist economy. Institutionalists consider capitalism as a monetary economy. Arestis and Eichner (1988) point to the close links between the post-Keynesian and institutionalist approaches as 
Keynes and Veblen, among others, have worked on the monetary theory of production where money is an endogenous and core variable letting capitalism evolve through an accumulation path. Polanyi (1944: 22) clearly underlines the importance of money and global interconnectedness through the analysis of the difficulties in the early $20^{\text {th }}$ century:

"Currency had become the pivot of national politics. Under a modern money economy nobody could fail to experience daily the shrinking or expanding of the financial yardstick; populations became currency-conscious; the effect of inflation on real income was discounted in advance by the masses; men and women everywhere appeared to regard stable money as the supreme need of human society. But such awareness was inseparable from the recognition that the foundations of the currency might depend upon political factors outside the national boundaries. Thus the social bouleversement which shook confidence in the inherent stability of the monetary medium shattered also the naïve concept of financial sovereignty in an interdependent economy."

Needless to say, the monetary and financial system's continuity is of paramount importance since monetary rules, regulatory mechanisms and financial markets allow (or not) private agents to undertake profit-seeking activities without any central coordination (Ülgen 2014a). This makes capitalism a complex society that requires appropriate monetary/financial institutions able to shape society's behavior toward consistent directions. Actually, in capitalist economies private expectations-based economic activities rest on the process of financing (debt relations) that involve bank credit and financial intermediation. This process of creation and accumulation of debts generates money creation, monetary production, monetary incomes and monetary consumption. Each step is dependent on the previous one but every step's expectations need to be confirmed by the realization of the next step. Debt-money circulation across the economy feeds financial relations, and financial markets involve (directly or 
indirectly) everyone into the market operations. Therefore, money is transversal since all economic transactions rely on monetary relations, and changes in money/financial markets affect the whole economy irrespective of decision units which are or are not involved in debt relations (Ülgen 2014b: 263). Transversal money also rests on ambivalence. Money lies indeed both in private decisions and public rules/constraints. It is created through private decisions of banks and entrepreneurs; it is a decentralized market outcome. Nevertheless, it is also the general unit of account (society's economic-quantitative language), means of payment and means of general/social debt-settlement. To give private debts and their circulation a general money power and to make society-wide debt-settlements possible money must lean on some societal (non-individual) public references/rules. As private debts circulate through the entire economy they involve the entire economy. At the same time, the accumulation process' sustainability lies in the systemic possibility to validate the debt structure (realization of expected profits). However, in such a non-ergodic economy there is no guarantee to validate the societal compatibility of separate decisions/actions. Some collective rules and mechanisms to organize and guide private actors' strategies with respect to systemic stability are thus required. Ambivalence of money, core role of financial mechanisms/relations in the economy but also for the existence of people imply that money and finance do not fit for private production. They have the characteristics of public goods and/or the commons even though finance is usually seen as rival and excludable by construction as it is produced and consumed through private relations. But as the publicness of a good means that its production and/or consumption affect the entire society and not only some private players; financial stability cannot be considered as a private good (or a common). In a society where the production and consumption rest on capitalist accumulation structures, the working and the continuity of economic relations rely on collective sustainability of monetary/financial mechanisms ${ }^{8}$. 
Furthermore, financial stability is a global public good that serves universally every member (of a country or a population) and every generation in the aim of meeting the needs of our grandgrand children without harming their development options. The sustainability depends on stable finance for stable growth and stable finance depends on the public production of collective rules (and values) that should control any excess of profit-seeking in the financial sphere.

\section{Social provisioning of financial stability: a matter of social consistency?}

If the design of institutions intends to make relations among people sustainable in order to allow society to evolve in a consistent way and if the dominant monetary/financial framework fails to give society such a consistency, then the search for alternative institutional forms to guide the economy in socially viable directions become more relevant and of utmost importance.

All the ingredients of a robust analysis of the stability conditions of capitalism may be found in institutionalism. Institutionalist theory -through the early works of Commons, Hamilton, Mitchell, Veblen and Clark, among others, puts the emphasis on the importance of monetary/financial relations, the central role of institutions/institutional change in economic evolution and on the issues related to systemic stability through collective action ${ }^{9}$. Minsky (1986) also maintains that economic evolution depends upon institutions, usages, and policies and is closely related to the impact of alternative institutional specifications. Alternative specifications must be organized and supervised through specific public/collective mechanisms. Basic principles for consistent reforms should aim at strengthening the organization and working of financial systems and reducing (if not preventing) systemic welfare-destroying crises. Minsky (1992) states that financial instability of capitalism and sophisticated financial system go together. Minsky (1982: 66) argues that market mechanisms cannot lead to full-employment 
equilibrium since: "The tendency to transform doing well into a speculative investment boom is the basic instability in a capitalist economy". This calls for alternative public regulation seeking systemic stability for societal viability ${ }^{10}$. If financial stability is a public good, its conservation and reproduction must be the principal task of every government which would provide society with appropriate financial infrastructures for the creation of trust and social capital in society, and enhancing the disposition of qualitative entrepreneurial action. In the same stance, Gruchy (1974) emphasizes that laissez-faire cannot be count on to provide social control, and the working of markets calls for continuous public vigilance. Then the provision of financial stability seems to be more suitable and relevant through public organization/supervision that would make financial markets a social provisioning process able to improve cohesion but also productive efficiency. This might result in a sort of balanced equilibrium under governmental direction in the tradition of Common's social/public control in economic affairs (Gruchy 1952). The emphasis might then be put on the government (or its agencies) role as a provider of a stable financial regulatory structure where the coercion would say: "Thou shalt not use finance to speculate at short run when public interests are involved". The basis of such a policy is that private individual economic freedom must be limited by the right and freedom of life for each citizen in society. Tight regulation and prevention of financial speculation are then the taxes that the market actors would have to pay for a sustainable system to which they belong. Because of the characteristics of monetary/financial capitalism and the non-ergodic nature of decentralized decision process, stability cannot be entrusted to market vicissitudes and liberal “after-deluge fines" imposed to individuals. To use a Hardin-like assertion (Hardin 1968: 1244), one may conclude that the inherent logic of money and finance remorselessly generates tragedy (of the markets) in liberalized finance capitalism. 


\section{Conclusion}

What is at stake in social provisioning analysis is the conception of an alternative framework: "Moreover, with agency and the provisioning process bracketed by the social fabric and social activities, the going economy as a whole cannot be reduced to simply a circuit of capital where the only interest of business enterprises and the capitalist class is to make more money." (Lee 2011: 1311)

This article sought to show that in such an aim, studying financial stability (more fundamentally, the conception and organization of monetary/financial systems) as a public good may offer a relevant angle of attack.

Private financial relations generate serious externalities from within that impact the whole economy. The main argument in this sense is the fact that money is transversal such as everyone is submitted to the consequences of financial evolution and especially of financial crises. It is not possible to prevent these externalities by giving individuals more property rights -which cannot protect people against the consequences of crises-. Everyone will suffer from the crises but also from the decisions of financing or not financing of financial institutions and banks according to their rumors and mood while everyone needs money and finance to exist in real life. In capitalism, finance and money are like food in biological life, they are excludable because they rests, at least partly, on private decisions and relations, but their exclusion and malfunctioning generate bad social outcomes. This calls therefore for public organization and supervision around some common/collective objectives. To deal with crises but also with the paradoxical question "why to make finance a public good", it would be suitable to give finance (at least) a semi-public status, for instance toward publicly supervised and organized financial inclusion systems. Even if we cannot entirely make capitalist finance a public good at the short run, we can submit its use and evolution to assessment criteria related to public wellbeing such 
as systemic stability, poverty reduction, employment enhancing, green and sustainable technology supporting, etc ${ }^{11}$. Remaining loyal to the liberal motto 'laissez-faire-first-and-punishthen" ${ }^{12}$ consists in locking the barn door after the horse had been stolen.

\section{References}

Arestis, Philip and Alfred S. Eichner. "The Post-Keynesian and Institutionalist Theory of Money and Credit”. Journal of Economic Issues 22, 4 (1988): 1003-1021.

Breger, Sasha. "Who Do Derivatives Markets Serve? Rhetoric Versus Reality". In Global Finance in the New Century. Beyond Deregulation, edited by Libby Assassi, Anastasia Nesvetailova and Duncan Wigan, pp. 55-73. Basingstock, Hampshire: Palgrave Macmillan and CGPE, 2007.

Dugger, William M. “A Research Agenda For Institutional Economics”, Journal of Economic Issues 22, 4 (1988): 983-1002.

Dugger, William M. "Redefining Economics: From Market Allocation to Social Provisioning". In Political Economy for the 21st Century: Contemporary Views on the Trend of Economics, edited by Charles J. Whalen, pp. 31-43. Armonk, New York: M.E. Sharpe, 1996.

Griffith-Jones, Stephany. "International Financial Stability and Market Efficiency as a Global Public Good”. In Providing Global Public Goods: Managing Globalization, edited by Inge Kaul, Pedro Conceicao, Katell Le Goulven and Ronald U. Mendoza, pp. 435-454. N. Y: Oxford University Press, 2003.

Gruchy, Allan. The Reconstruction of Economics: an analysis of the fundamentals of Institutional economics. New York: Greenwood Press, 1987.

"Government Intervention and the Social Control of Business: The

Neoinstitutionalist Position”. Journal of Economic Issues 13, 2 (1974): 235-249. 
. "The Economics of Collective Action". American Economic Review, 42 (1952):

$141-145$.

Hardin, Garrett. "The Tragedy of the Commons”. Science 162 (1968): 1243-1248.

Hopkin, Jonathan and Mark Blyth. "What can Okun teach Polanyi?: efficiency, regulation and equality in the OECD.” Review of International Political Economy 19, 1 (2011): 1-33.

Lee, Frederic S. "Modeling the Economy as a Whole: An Integrative Approach". American Journal of Economics and Sociology 70, 5 (2011): 1282-1314. . and Marc Lavoie. (Eds.) In Defense of Post-Keynesian and Heterodox Economics: Responses to their Critics. Routledge, Abingdon, Oxon, UK, 2013. (Ed.) Social Provisioning, Embeddedness, and Modeling the Economy: Studies in Economic Reform and Social Justice, Wiley-Blackwell, 2012.

Lindsay, C.M. and William R. Dougan. "Efficiency in the provision of pure public goods by private citizens”. Public Choice 156 (2013): 31-43.

Machan, Tibor R. "The Calculation Problem and the Tragedy of the Commons: Two Sides of the Same Coin?" Economics, Management, and Financial Markets 5, 4 (2010): 54-62.

Minsky, Hyman P. Can "It" Happen Again? Essays on Instability and Finance. Armonk, N.Y. Sharpe Inc., 1982. . Stabilizing an Unstable Economy. Yale University Press, 1986. . "The Financial Instability Hypothesis”. The Jerome Levy Economics Institute of Bard College Working Paper No. 74 (1992).

Olson, Mancur. The Logic of Collective Action. Public Goods and the Theory of Groups. $20^{\text {th }}$ printing, Harvard University Press, Cambridge, Mass. [1965] 2002.

Ostrom, Elinor. Governing the Commons. The Evolution of Institutions for Collective Action. 22 $2^{\text {nd }}$ printing, Cambridge University Press, NY, [1990] 2008. 
Polanyi, Karl. The Great Transformation. The Political and Economic Origins of Our Time. Ninth printing, Beacon Press, Boston, [1944] 1968.

Power, Marilyn. "Social Provisioning as a Starting Point for Feminist Economics". Feminist Economics 10, 3 (2004): 3-19.

Tae-Hee, Jo. "Social Provisioning Process and Socio-Economic Modeling". The American Journal of Economics and Sociology 70, 5 (2011): 1094-1116.

Todorova, Zdravka. "Connecting social provisioning and functional finance in a postKeynesian-Institutional analysis of the public sector". European Journal of Economics and Economic Policies: Intervention 10, 1 (2013): 61-75.

Ülgen, Faruk. "How to Guide the Economy in a Socially Desirable Direction? Lessons from the 2007 Financial Turmoil”. Journal of Economic Issues 4, 2 (2014a): 575-584. "Schumpeterian economic development and financial innovations: a conflicting evolution”. Journal of Institutional Economics 10, 2 (2014b): 257-277.

\footnotetext{
${ }^{1}$ See, for instance, Machan (2010) and Lindsay and Dougan (2013).

${ }^{2}$ Real equilibrium models regard monetary/financial systems as technical details and have no room for specific analysis of sophisticated financial structures and related instability concerns that a capitalist economy can generate in its own evolution.

${ }^{3}$ In Breger (2007: 55).

${ }^{4}$ Although very crucial and related to the core questions of this article, this issue is not studied in this essay. However, a very interesting analysis can be found in the work of Hopkin and Blyth (2011) where the debate between Okun's assertion that the efficiency is incompatible with equality and Polanyi's assertion that embedded markets result in better social outcome is studied through some relevant arguments.
} 
${ }^{5}$ One cannot exclude others from using the good.

${ }^{6}$ Its use by one individual does not reduce its availability -quantitatively and qualitatively speaking-for others, at least until congestion occurs.

${ }^{7}$ In other words, the radical opposition between public and private organizations is related to the opposition between two basic principles: "free access and collective control of the use" versus "supply/demand pricing-based private market mechanisms".

${ }^{8}$ But at the same time, it is worth noting that when the public power is weak, the provision of public-like goods is disturbed and things become rival (general access restricted) and excludable (lack of collective means resulting in poverty, illiteracy, etc.). This is a sign of societal malfunctioning that may result in crisis.

${ }^{9}$ See Ulgen (2014a) for related references.

${ }^{10}$ Related to the issue of financial instability of capitalism, Ülgen (2014b) remarks the relevance of the institutionalist Minsky-Schumpeter connexion since Schumpeter and Minsky both study capitalism as an institutionally framed evolutionary process along with unstable financial dynamics.

${ }^{11}$ At a more radical level, the whole system might become public good with free access but not free "abuse".

${ }^{12}$ This consists of some "after crisis interventions" that generate huge social costs and result in no structural improvement of monetary and financial architecture. 